Proc. Estonian Acad. Sci. Biol. Ecol., 2001, 50, 4, 231-247

\title{
THE INFLUENCE OF CURRENTS AND WAVES ON ECOLOGICAL CONDITIONS OF THE VÄINAMERI
}

\author{
Ülo SUURSAAR, Tiit KULLAS, and Mikk OTSMANN
}

Estonian Marine Institute, University of Tartu, Paldiski mnt. 1, 10137 Tallinn, Estonia; ys@ sea.ee

Received 27 February 2001, in revised form 27 June 2001

\begin{abstract}
Based on field measurements (1993-99) and hydrodynamic modelling the influence of currents on the ecological situation of the Väinameri is analysed and an introductory study on the resuspension is reported. 2D flow charts are presented. The Väinameri is a highly dynamic water body, where the situation is mostly determined by the water exchange processes forced by two major nearby basins (i.e., the Baltic Proper and the Gulf of Riga) and resuspension events during storms. The hydrophysical and hydrochemical front fluctuates in $\mathrm{N}-\mathrm{S}$ direction and the local conditions are frequently overrun by these excursions. Resuspension events due to currents (in the straits) and surface waves (in the shallow parts of the Väinameri) affect the study area with high turbidity and cause an about 2-3-fold increase in phosphorus concentrations. On the basis of hydrodynamic behaviour two sub-basins could be defined in the Väinameri. The eastern part has about $85 \%$ of the water exchange, lower salinity, and higher nutrient concentrations. In the western section hydrological conditions are more marine and less variable.
\end{abstract}

Key words: currents, fronts, waves, resuspension, nutrients, modelling, Baltic Sea.

\section{INTRODUCTION}

It is generally a well-known fact that hydrodynamic processes are the basic agents that alter the concentrations and spatial distributions of biologically important nutrients and pollutants in the coastal marine areas. In the present paper we aim to describe two important mechanisms in the case of a relatively shallow and semienclosed basin of the Väinameri. Wind wave motions and other sea-level fluctuations reach to influence bottom life and sediments. Special importance of currents appears due to the complex configuration of the study area. Velocities are higher in the straits than in the open sea, producing considerable bottom stress and material displacement. Currents also have specific importance in the coastal 
zone and near estuaries due to their association with water exchange processes and frontal movements (Bowman \& Esaias, 1977). Besides these two processes some other less important hydrodynamic phenomena, such as Langmuir circulation and upwellings (indirect influence in the case of the Väinameri), could be listed. Sea level simulations in the study area are presented in Suursaar et al. (2001). The influence of sea level oscillations (variation range is $2.5 \mathrm{~m}$ at Rohuküla) combines largely with wave action. This influence is not specially analysed here, but level (and depth) changes are calculated and taken into account both in flow and wave models.

Other major factors competing with the above-mentioned hydrodynamic processes are seasonality and the so-called local conditions: freshwater inflow from rivers and local nutrient and pollution load. It is known that in the region of the Baltic Sea rivers are responsible for about $70-90 \%$ of the total nutrient input (HELCOM, 1993; Pitkänen, 1994). The most simplified traditional view on the coastal areas could be therefore summarized as follows: the (Kasari) river pollutes the (Matsalu) bay, the bay pollutes the sea (first the Väinameri and finally the Baltic Proper). As a result, the anthropogenic influence should gradually decrease towards the open sea. Alternatively to that somewhat static model we are going to show that the Väinameri is a highly dynamic system, where water masses with different properties counteract and transform, and where shallowwater hydrodynamic processes play a crucial role in forming the ecological conditions.

\section{STUDY AREA}

The Väinameri (Muhu Straits, Moonsund, sometimes also the Archipelago Sea) is a relatively small marine area between the western coast of Estonia and the West-Estonian Archipelago. It has an area of $2243 \mathrm{~km}^{2}$ and a volume of $10.6 \mathrm{~km}^{3}$. Five narrow straits connect it with neighbouring marine areas (Fig. 1). Two major straits lie along the N-S direction: Suur Strait (width $4 \mathrm{~km}$, maximum depth $22 \mathrm{~m}$, cross-section area $0.04 \mathrm{~km}^{2}$ ) and the Hari Strait (width $8 \mathrm{~km}$, depth $10 \mathrm{~m}$, cross-section area $\left.0.045 \mathrm{~km}^{2}\right)$. The shallow Voosi Strait $(2 \mathrm{~km}, 2 \mathrm{~m}$, $0.004 \mathrm{~km}^{2}$ ), which is next to Vormsi Island and parallel to the Hari Strait, carries no special importance in the present study. The parallel counterpart to the Suur Strait, the Väike Strait, has been closed by a road dam and has no water exchange at all. The remaining Soela Strait $\left(4 \mathrm{~km}, 4 \mathrm{~m}, 0.01 \mathrm{~km}^{2}\right)$ is the only one of W-E orientation.

The Väinameri has a complex coastal line and bottom topography. In the eastern section are located two bays, Haapsalu Bay and Matsalu Bay, which are among the most eutrophied bays in the whole Estonian coastal zone. Shallow Matsalu Bay (area $67 \mathrm{~km}^{2}$, volume $0.1 \mathrm{~km}^{3}$ ) receives an inflow from the $113 \mathrm{~km}$ long Kasari River $\left(1 \mathrm{~km}^{3} / \mathrm{yr}\right)$, which drains a catchment area of $3230 \mathrm{~km}^{2}$ (Mardiste \& Kaasik, 1985). Haapsalu Bay, just north of Matsalu Bay, is roughly 


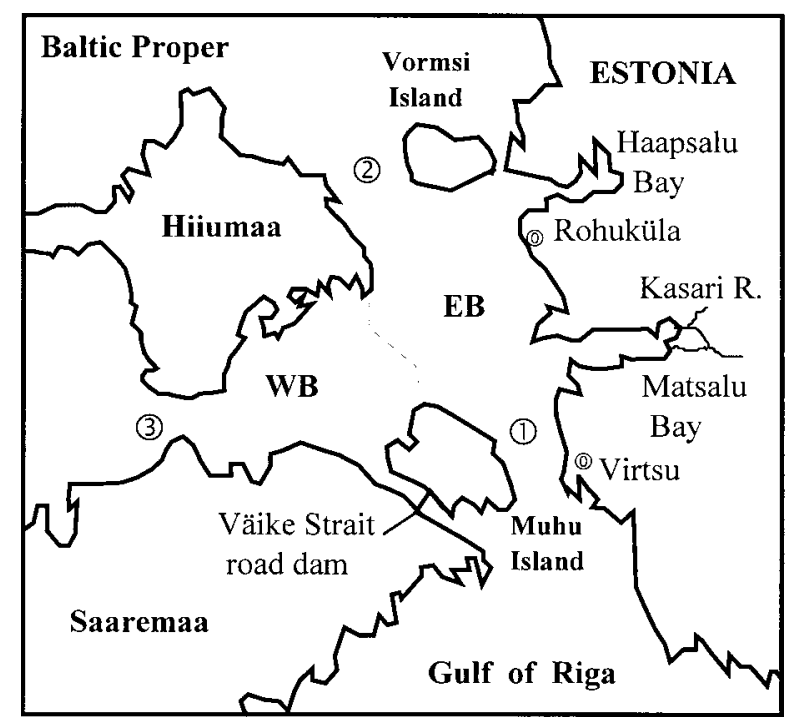

Fig. 1. The northern part of the Gulf of Riga and the Väinameri. 1, Suur Strait; 2, Hari Strait; 3, Soela Strait; EB, eastern sub-basin; and WB, western sub-basin (also Kassari Bay) of the Väinameri.

of the same size. There is no considerable riverine inflow into this bay, instead it receives some pollution load from the town of Haapsalu (14 000 inhabitants).

In some preliminary papers we described mainly temporal variations of the flows in the straits without a horizontal aspect (e.g. Suursaar et al., 1996). Because of lack of information we assumed the Väinameri to be a single buffer zone or a "mixing box". According to our latest field studies and 2D hydrodynamic modelling presented in this paper two sub-basins should be differentiated in the Väinameri. Following the section along islets and shoals between the eastern tip of Hiiumaa and Muhu islands the western basin (WB) and the eastern basin (EB) can be defined (Fig. 1). The total length of the section is about $19 \mathrm{~km}$, from which islets (Kaevatsi, Hanikatsi, Vareslaid, Kõrglaid, Ahelaid) cover about $5 \mathrm{~km}$, depths of 1-2 m dominate on the length of $7 \mathrm{~km}$ and only $6-7 \mathrm{~km}$ has depths $4-5 \mathrm{~m}$ (max $5.5 \mathrm{~m}$ ). The corresponding cross-section area is $0.028 \mathrm{~km}^{2}$, which is less than in the Suur or Hari straits. Actually it could be regarded as a strait between the WB and the EB, as the largest cross-section across the WB is about 4 times as large as the section under discussion. Hydrological conditions in a similarly specified area (also called Kassari Bay) were described by Mardiste (1974a). The surface area of the WB forms about $38 \%$ of the Väinameri area and the volumes are $33 \%$ for the WB and $67 \%$ for the EB. The EB is nearly as shallow as the WB, average depths are respectively about 5 and $4 \mathrm{~m}$. Maximum depths are 9-10 m for the WB and nearly $22 \mathrm{~m}$ for the EB (near Kessulaid Islet). Apart from one relatively deep place, depths from 3 to $8 \mathrm{~m}$ dominate in the Väinameri. 


\section{MATERIALS AND METHODS}

The study is based on the field work carried out under different research projects (Gulf of Riga Project, grant projects) in 1993-99 and on hydrodynamic modelling. Measurements in the Väinameri area include about 640 days of flow measurements, mostly in the Suur Strait, and data from 16 field campaigns (thermohaline regime, nutrients, oxygen, relative transparency, meteorological data). An overview can be found in the reports (Suursaar \& Astok, 1996, 1998) and some papers (Suursaar et al., 1996; Astok et al., 1999).

Hydrodynamic modelling was carried out using a forced oscillation model for the water exchange (Otsmann et al., 1997, 2001) and by the $2 \mathrm{D}$ hydrodynamic model (Kullas et al., 2000; Suursaar et al., 2000). Depth-averaged flow models are appropriate for vertically mixed (non-stratified) shallow water bodies like the Väinameri is. For the present study a series of model simulations were carried out for describing currents both in the straits and offshore regions, and for clarifying some findings from the field experiments.

The 2D hydrodynamic model domain includes the Gulf of Riga $(1 \mathrm{~km}$ mesh, 16405 gridpoints) together with the Väinameri (2510 points). The simulation sets use realistic data: HIRLAM winds and sea level data in the open boundaries calculated from the Baltic Sea 2D model (for 1995) or measured single-point sea level and wind data (for 1999). The outputs include time series of velocities and sea levels at gridpoints with $1 \mathrm{~min}$ time step. The snapshots presented in this study show 1995 simulations, as they are backed with field measurements. Only the northern part of the modelled area is shown in the snapshots, while the computation covered the whole model domain. Some preliminary runs with wave and resuspension models were also performed. Wave calculations were carried out using a first generation wave model, based on the SMB method (see e.g. Huttula, 1994). The resuspension model coupled to our 2D model is called HSCTM-2D (Hydrodynamic Sediment and Coastal Transport Model, see also Hayter et al., 1998).

\section{RESULTS AND DISCUSSION \\ Influence of resuspension generated by waves and currents}

Resuspension brings already deposited inorganic and organic material into suspension through stressing bottom sediments by currents and wave action. It influences biogeochemical processes via sediment displacement, underwater light conditions, and enrichment of the water column by particles with nutritional potential. Nutrient regeneration supports most of the primary production in shallow coastal areas (Massel, 1999). The erosion of sediments is an important mechanism for secondary pollution by particulate bound contaminants (e.g. heavy metals) accumulated in the sediments during the last 50-100 years (Puls et al., 1999). 
Dependence of transparency on wind conditions was stated in the Väinameri by Mardiste (1974b). He reported remarkably high values (up to $14 \mathrm{~m}$ ) as opposed to commonly lower present-day values. The decreasing trend in the Gulf of Riga during the last 30-40 years (e.g. Berzinsh, 1995) may be explained mainly by eutrophication and possibly also by increased windiness. Storminduced resuspension events were observed several times during our field work in 1993-95. In the Suur Strait area we typically registered about a two-fold rapid increase in the total phosphorus content during storm events and a gradual decrease down to the initial values in the course of about two days after the storm (Suursaar \& Astok, 1996). Synchronous variations in $\mathrm{P}-\mathrm{PO}_{4}$ concentrations were observed as well. Concentrations from the near-bottom layer (11-13 m) were higher (1.2-fold on average) than in the upper layer $(0-6 \mathrm{~m})$. Water turbidity increased and transparency decreased usually from $2-3 \mathrm{~m}$ to $0.8-1.2 \mathrm{~m}$. Relationships between wind velocity and transparency $(r=-0.56)$, wind and $\mathrm{P}_{\text {tot }}$ $(r=0.63)$, transparency and $\mathrm{P}_{\text {tot }}(r=-0.74)$, based on relatively sparse data, are illustrated by Fig. 2. In reality these relationships are stronger than the given correlation coefficients hint due to the following factors: (a) Data from several expeditions were used, representing different seasonal phases and water masses. (b) Low preciseness of Secchi measurements; transparency was measured incidentally and some potentially interesting data are missing during storms. (c) Existence of a time lag between stress and effect due to cumulative effect or "history" of variables. (d) The relationships are not linear, using exponential functions we obtained $r=-0.81$ between $\mathrm{P}_{\text {tot }}$ and transparency (Suursaar et al., 1996). Certain threshold for wind velocity exists when the water turbidity increases rapidly (about $8-10 \mathrm{~m} / \mathrm{s}$ for the Väinameri). As the correlation was stronger with $\mathrm{P}_{\text {tot }}$, it could be hypothesized that the increase in phosphorus

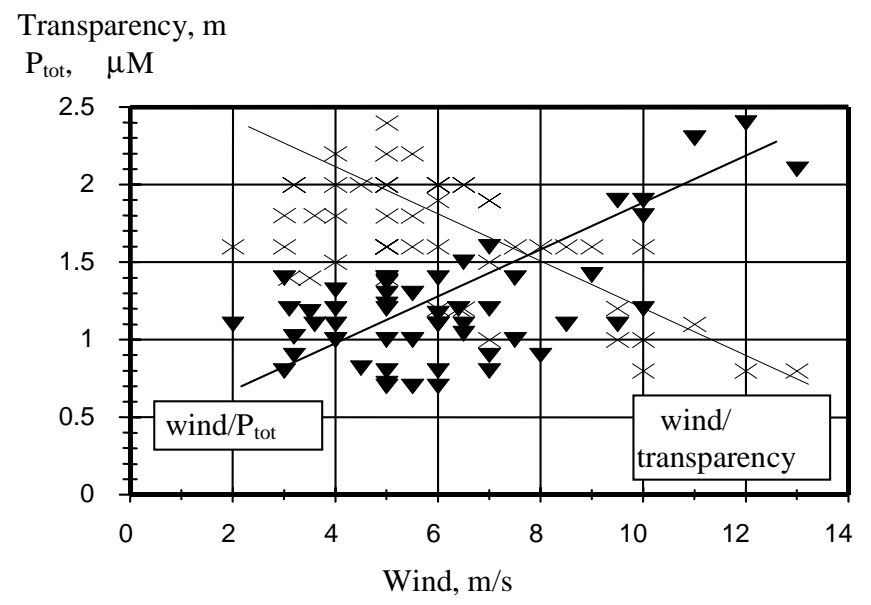

Fig. 2. Relationships between the wind velocity, transparency, and $\mathrm{P}_{\text {tot }}$ measured in the region of the Suur Strait in 1993-95. 
concentrations starts before the water turbidity increases. This feature is also described in a laboratory experiment with resuspensiometer by Laima et al. (1994). The strongest flux of phosphorus from the sediments was observed in the first phase of the bottom stress increase in the experiment. Increase in turbidity appeared under somewhat stronger stresses and with a time lag, while decrease in $\mathrm{O}_{2}$ occurred only at very intensive stirring.

From a practical perspective it is an important task to describe (to model) sedimentation-resuspension processes in the study area for specifying bottom areas and periods of time of sedimentation or resuspension. Settling of detritus and partly decomposed algae increases in spring and summer just after bloom. These are also relatively calm seasons in the Väinameri. During autumn and winter storms such material is brought back to the water column and currentdriven displacement increases. Frequent resuspension supports the normal gradual increase of nutrient concentrations in autumn. As bottom stress increases exponentially with wave-orbital or current velocity, all major changes in the bottom sediments or coasts take place during relatively short periods of time, namely during storms. According to the literature, in a shallow coastal zone sediment transport may increase up to 60 times during storms as opposed to calm conditions (Massel, 1999). Thus, we can also expect major filling up of the dredged fairways along the ferry routes of the Väinameri to take place during storms.

Storms stress bottom both by wave action and by currents. In nature these two processes act simultaneously and are hardly distinguishable, but in the model they require different blocks (submodels). Several mathematical models exist for erosion-settling-resuspension processes (e.g. Haupt et al., 1999; Jiang et al., 2000; Lou \& Schwab, 2000). Ideally they take into account the granulometric composition of sediments, coagulation and aggregation, existence of bottom vegetation, properties and depositional history of layers, and inclination of the bottom slopes (as in addition to currents, slopes of only $0.5^{\circ}-1^{\circ}$ are enough for directing sediment movements). At present we are able to model 2D velocity fields in the Gulf of Riga and the Väinameri (Figs. 3-4), to calculate currentinduced bottom stresses in the gridpoints, and resuspension (see also Suursaar et al., 2000). A preliminary snapshot in Fig. 5b shows high suspended matter concentrations in the relatively shallow coastal areas, where the thin water column saturates rapidly with suspended sediments. According to our measurements strong north wind evoked current velocities of up to $0.9 \mathrm{~m} / \mathrm{s}$ in the Suur Strait on 2 January 1995 (Suursaar \& Astok, 1996). The content of suspended solids could be sampled for verification and comparison, but it should be possible to retrieve suspended matter concentrations from satellite images using special algorithms (Li et al., 1998), for example, zones of turbid water are visible on a LANDSAT image of the Väinameri (see Peterson et al., 1998).

Rough estimates show that in the near-bottom layer the current velocities required for resuspension and deposition of sand are about 0.6 and $0.3 \mathrm{~m} / \mathrm{s}$, respectively (e.g. Haupt et al., 1999; Massel, 1999). The values are smaller for 

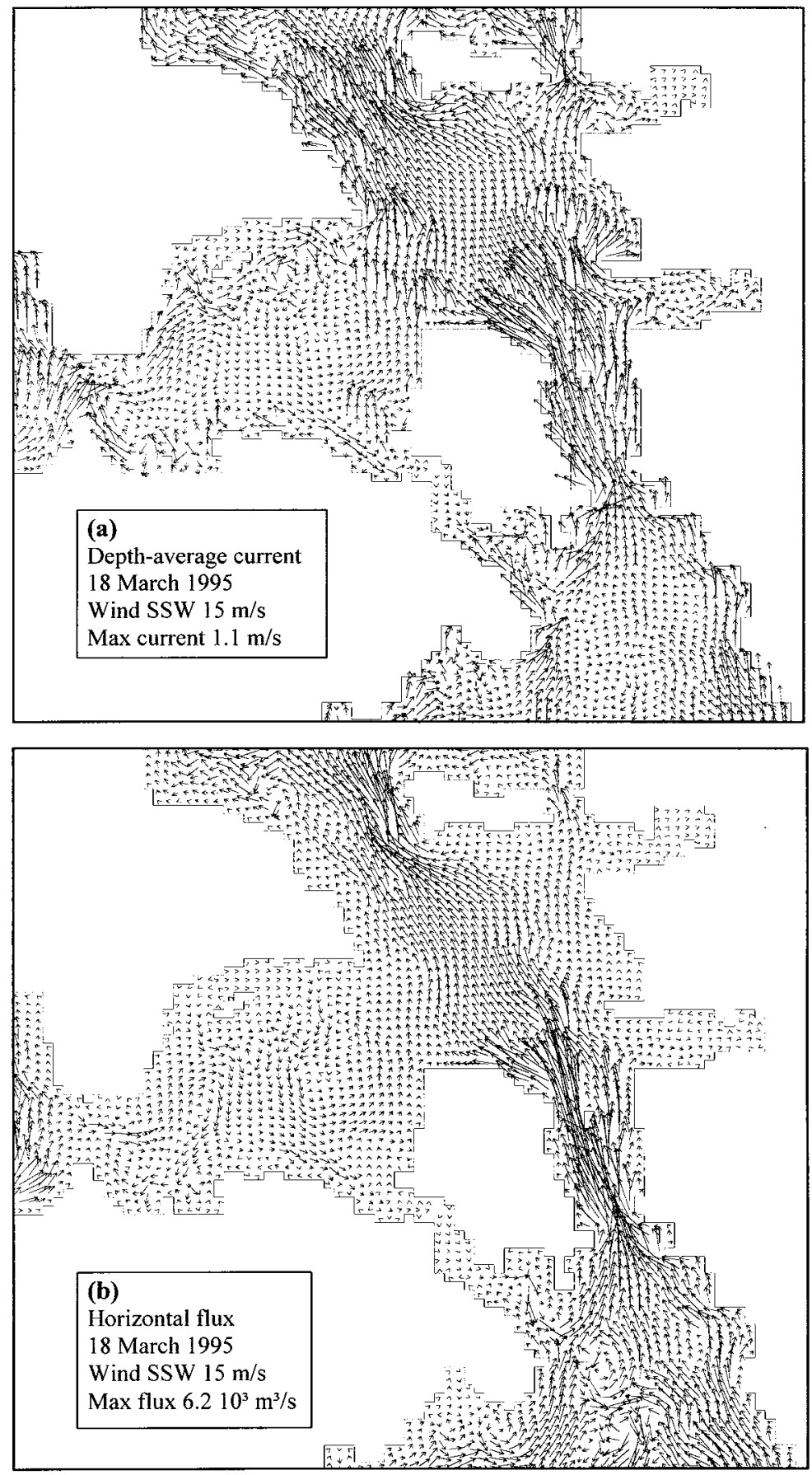

Fig. 3. Snapshots of currents (a) and the corresponding water fluxes (b). For fluxes the depthaverage velocities are multiplied by depths in the gridpoints and by $1 \mathrm{~km}$, which comes from the corresponding horizontal grid-step. 

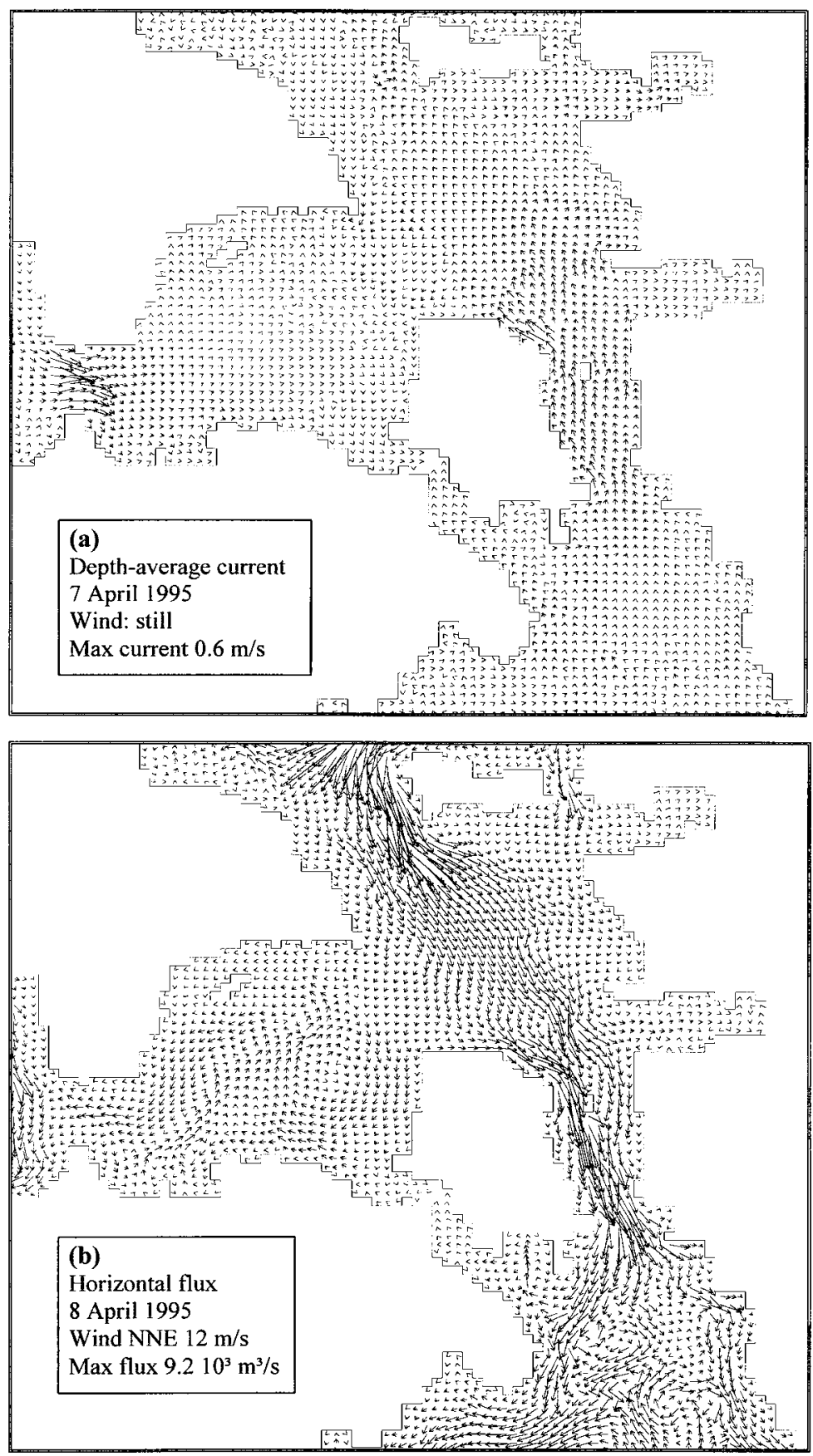

Fig. 4. Snapshots of currents during still conditions (a). Maximum velocities $(0.6 \mathrm{~m} / \mathrm{s})$ appeared occasionally in the Soela Strait. Horizontal fluxes one day later (b). 

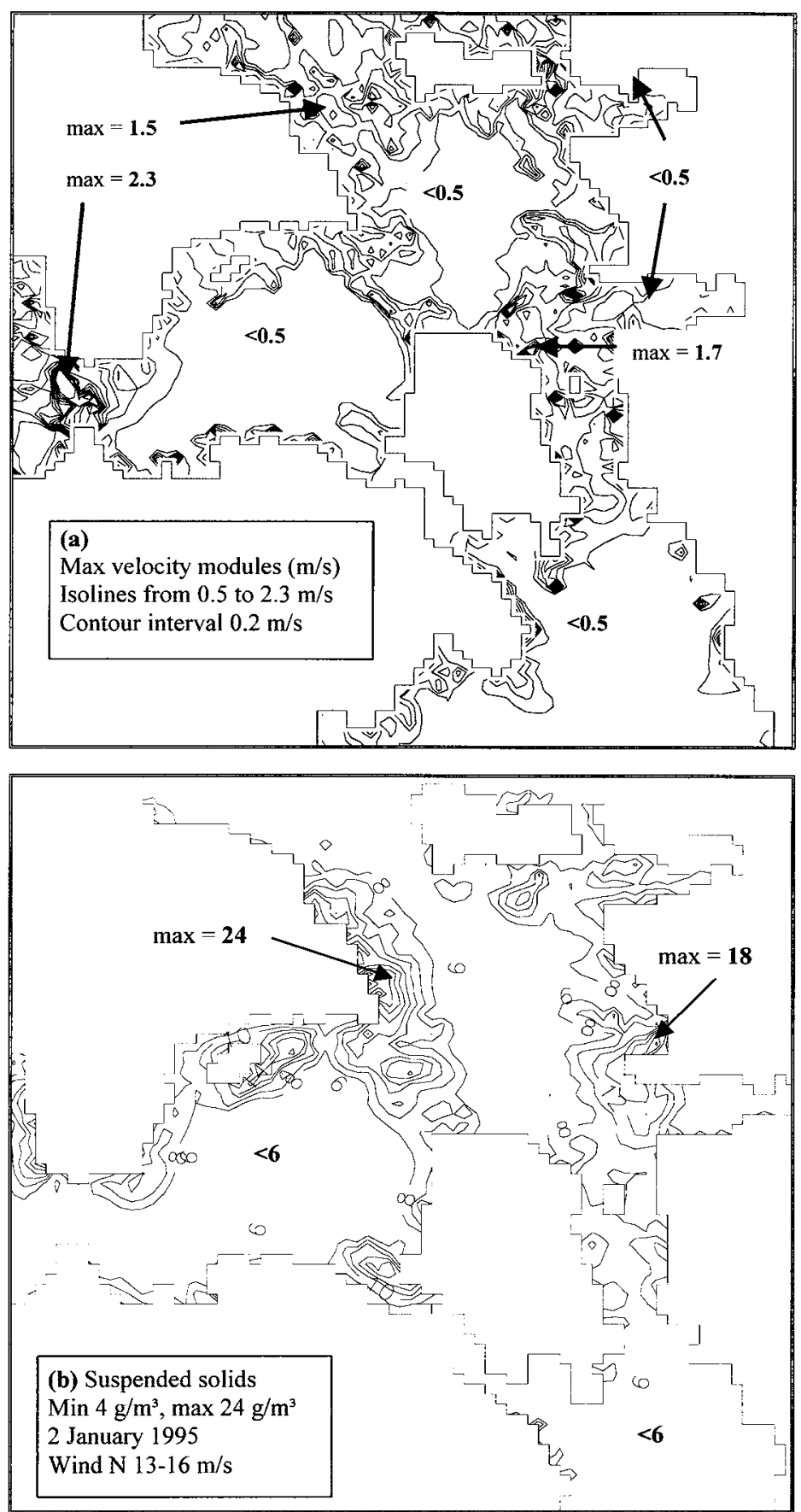

Fig. 5. Maximum possible current velocities in the Väinameri modelled on the basis of the whole year of 1995 (a), snapshot of the modelled content of suspended solids (b). 
fine particles (mud, clay). Maximum possible flow velocities reach $1.5-2.3 \mathrm{~m} / \mathrm{s}$ in the straits (Fig. 5), but also some relatively calm zones exist, where velocities never exceed $0.5 \mathrm{~m} / \mathrm{s}$ or even $0.3 \mathrm{~m} / \mathrm{s}$. Despite large velocities in the Soela Strait, the zonal flows scatter markedly within the WB. Considering that the maximum meridional cross-section area through the WB is 9-10 times larger than in the Soela Strait, the maximum velocities in the central part of the basin are about $0.2-0.3 \mathrm{~m} / \mathrm{s}$. A somewhat similar basin in the middle of the EB has current velocities of about $0.3-0.5 \mathrm{~m} / \mathrm{s}$.

According to the literature (Kirikal, 1967; Mardiste, 1974b) the maximum measured local wave height is $1.3 \mathrm{~m}$ inside the Väinameri. The small size and shallowness of the basin do not permit high waves, but in some places near the Hari Strait waves up to $2.5 \mathrm{~m}$ may be imported from the open Baltic in favourable wind conditions. Applying wind velocity of $20 \mathrm{~m} / \mathrm{s}$ as an extremal situation and fetch distance of $40 \mathrm{~km}$, significant wave heights, periods, and near-bottom horizontal velocities were calculated using the first generation wave model for different depths of the Väinameri (Table 1). In the shallow zone (1-4 m) the maximum velocities of the wave motions were $0.8-1.1 \mathrm{~m} / \mathrm{s}$, in the depths between 7 and $10 \mathrm{~m}$ the velocities were $0.3-0.6 \mathrm{~m} / \mathrm{s}$, and the velocities decreased to $0.04-0.1 \mathrm{~m} / \mathrm{s}$ in the depths of 20-25 m. Comparing these results with Fig. 5a we can conclude that in the regions of straits resuspension generated by currents dominates, while in the shallow coastal areas in the eastern and north-eastern sections of the EB wave erosion prevails. In some deeper offshore areas sedimentation and accumulation processes predominate. According to the dominant process that operates on the coast various coasts have been generally designated as wave-dominated or tide-dominated (Davis \& Hayes, 1984). In the case of the Väinameri the oscillating currents in the straits and frequent sea level fluctuations create similarity with moderate tidal effects, so that we can speak about wavedominated and current-dominated coasts.

Table 1. Increase of possible wave heights and decrease in near-bottom orbital velocities with depth. Simulation results with $20 \mathrm{~m} / \mathrm{s}$ wind and $40 \mathrm{~km}$ fetch

\begin{tabular}{l|c|c|c|c|c|c|c}
\hline & \multicolumn{7}{|c}{ Depth, m } \\
\cline { 2 - 8 } & 1.00 & 2.00 & 4.00 & 6.00 & 10.00 & 15.00 & 25.00 \\
\hline Wave height, m & 0.38 & 0.64 & 1.07 & 1.45 & 2.11 & 2.83 & 4.06 \\
Wave period, s & 3.14 & 4.04 & 5.15 & 5.91 & 6.97 & 7.87 & 9.03 \\
Velocity 0.5 m from bottom, $\mathrm{m} / \mathrm{s}$ & 1.08 & 1.05 & 0.87 & 0.67 & 0.38 & 0.19 & 0.04
\end{tabular}

The major zone of accumulation is located in the central part of Kassari Bay both according to geological investigations (Lutt, 1985) and hydrodynamic considerations. Another factor favouring deposition in this area is hollow bottom topography with prevailing depths of 7-10 $\mathrm{m}$. Accumulation is also possible in some isolated depressions along the Suur and Hari straits. These zones can be also found in the existing sediment maps (thickness of Holocene deposits, granulometric distributions) of the Väinameri (see Lutt, 1985). 


\section{Influence of frontal excursions driven by currents}

Currents seem to be the crucial factor for the state of the Väinameri since the front dividing quite different water masses (the Gulf of Riga estuarine-type and the Baltic Sea marine-type) moves north- or southwards depending on the prevailing winds and currents. While the long-term average concentrations of phosphates in the Gulf of Riga are about $0.4-0.8 \mu \mathrm{M}$ in early winter and the typical values for nitrates are about $10-20 \mu \mathrm{M}$, the corresponding values in the Baltic Proper and in the entrance section of the Gulf of Finland are about 0.3-0.6 $\mu \mathrm{M} \mathrm{PO}_{4}$ and 4-10 $\mu \mathrm{M} \mathrm{NO}_{3}$ (Pitkänen, 1994; Suursaar, 1994; HELCOM, 1996). Eliminating the influence of seasonality the corresponding $\mathrm{P}_{\text {tot }}$ and $\mathrm{N}_{\text {tot }}$ concentrations in the gulf are roughly twice as high as in the open sea.

It was found that while the dependence of the phosphorus content on the currents is usually weak, a connection between the currents, the nitrogen content, the salinity, and some other variables can often be observed in the Väinameri, especially when the flow has been quasi-stationary for some days (Suursaar \& Astok, 1996; Astok et al., 1999). One dramatic example from the autumn of 1996 showed a strong inflow of cold, relatively saline and nutrient-poor water from the north (Fig. 6), which originated from the upwelling phenomenon generated in the southern slope of the entrance section of the Gulf of Finland. Strong north-eastern winds resulted in Ekman transport, the upwelled water was further transported into the zone of straits. Wind-induced coastal upwellings are considered a common phenomenon appearing in favourable wind conditions along several sections of the Baltic coast (Gidhagen, 1984). The eastern half of the Väinameri was filled by the water with a temperature of about $5^{\circ} \mathrm{C}$ and salinity of 7.2 PSU. Nutrient concentrations were very low and water transparency was high (6-7 m against typical 2-3 m). About two weeks later, when the southern winds prevailed it took 3-4 days to refill most of the EB of the Väinameri by the Gulf of Riga water $\left(4 \mathrm{~km}^{3}\right.$, Fig. $\left.6 \mathrm{~h}\right)$ and the front to reach the Hari Strait. The water temperature rose up to $10^{\circ} \mathrm{C}$, which is typical of that season, salinity dropped down to $5.8 \mathrm{PSU}$, and transparency to $1.8-2.8 \mathrm{~m}$. About $7 \mathrm{~km}^{3}$ of water left during the whole outflow event (Fig. 6h).

The prominent salinity difference of 1.3-1.5 PSU measured by us is not important in comparison to coastal marine areas of high salinity (e.g. fjords and oceanic estuaries). In the conditions of the brackish water of the Baltic Sea this difference still indicates the existence of a front, as extremes for the Suur Strait are only 5 and 7.1 units (Suursaar et al., 1996). However, in average nutrient concentrations up to 2-3-fold differences appear (Fig. 6) and even bigger differences may appear in some hydrochemical and -biological variables.

Though such frontal excursions can take place any time, there is usually one northern maximum position of the front during a year and one southern position. The forcing for such seasonality is the seasonal pattern of the water exchange processes of the whole system governed by the large-scale atmospheric circulation above the North Atlantic (Suursaar \& Astok, 1998). The main water exchange is 
18-19.09.1996 (N wind) Hari St. time series 18.09-14.10.96 14.10.1996 (S wind)
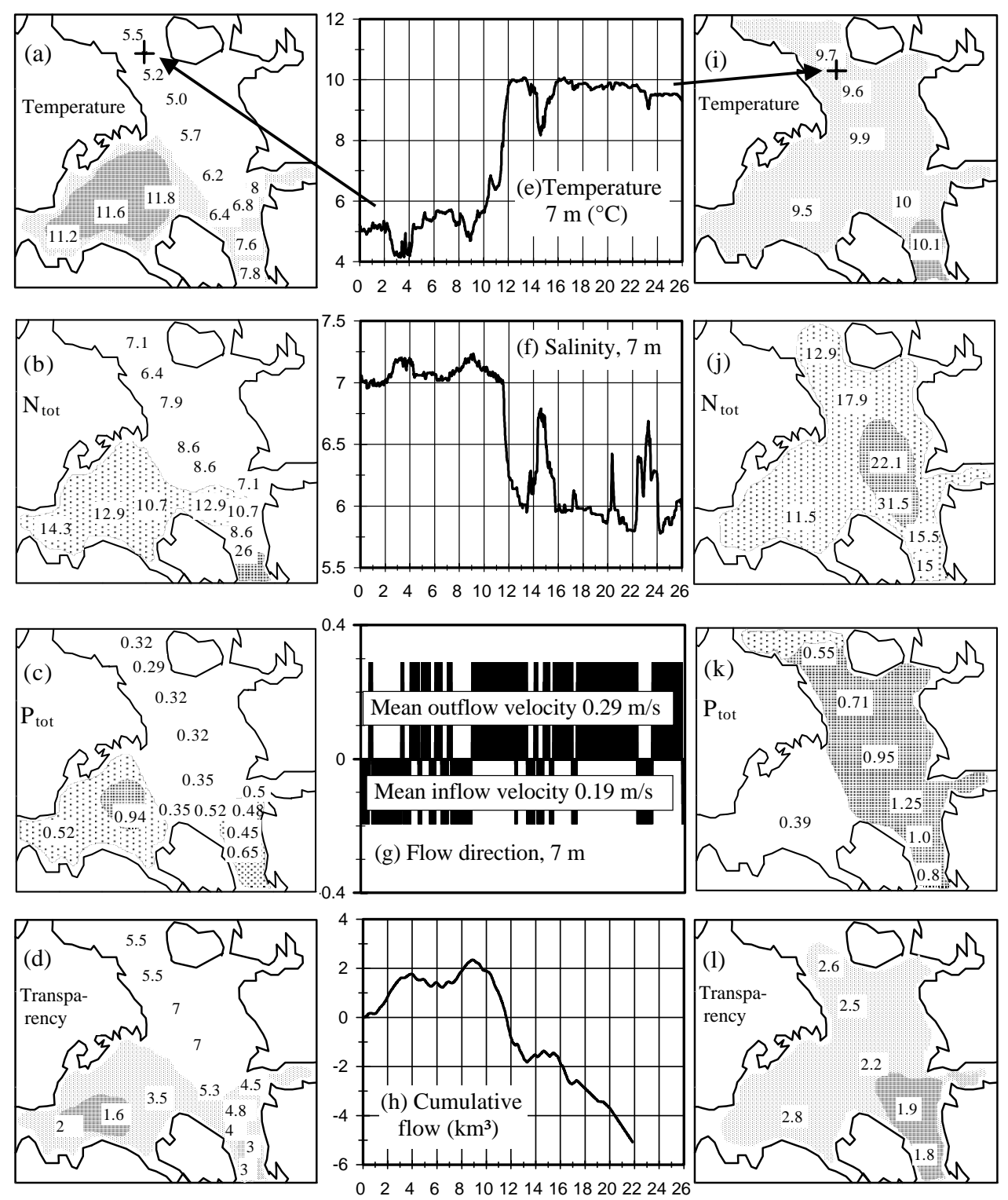

Days from 18.09.1996

Fig. 6. Influence of frontal pulsations in autumn 1996. Time series measured at the Hari Strait $(\mathrm{e}-\mathrm{h})$ and the corresponding situation for the inflow regime from the Baltic Proper $(\mathrm{a}-\mathrm{d})$, and the outflowing regime from the Gulf of Riga a few weeks later (i-l). The arrows (between e/a and e/i) connect the corresponding values. Inflow means $\mathrm{S}$-direction and outflow $\mathrm{N}$-direction (g). Nutrient concentrations in $\mu \mathrm{M}$. 
meridional and wind directions $90^{\circ}$ and $270^{\circ}$ serve as the breaking points for such flows. It is enough that $\mathrm{N}-\mathrm{S}$ wind component had seasonality and according to long-term statistics (in Virtsu station near the Suur Strait) wind has a northward component of 0.2-1.4 m/s between September and April and a southward component of $0.1-0.6 \mathrm{~m} / \mathrm{s}$ between May and August (Kull \& Meitern, 1998). According to wind statistics we can expect inflows (southward motions) to prevail from May to August and outflows in autumn and especially during mild (stormy) winters.

Another important feature appears in Fig. 6. The WB, which is slightly separated from the EB by a grid of islets, was quite passive in the case of $\mathrm{N}-\mathrm{S}$ circulation. This means that the Väinameri does not act as a uniform water body. The front moved rapidly through the eastern section of the Väinameri and the western section remained separated by a sub-front. The water trapped in the WB represented properties of the previous flow event. A sub-front was also observed in October 1997 (Fig. 7) and again in October 1998. Considering 2D model simulations (Figs. 3-5) and flow calculations using the forced oscillation model, the situation should be quite typical: the WB appears to be more marine and less dynamic than the EB. Considering the volume $\left(3.5 \mathrm{~km}^{3}\right)$ and the velocity of average inflow through the Soela Strait $(0.37 \mathrm{~m} / \mathrm{s})$, filling up the basin takes about 18 days. In comparison, the same rate for the EB $\left(7.1 \mathrm{~km}^{3}\right)$ through the Suur and Hari straits is about 7-8 days. In the Soela Strait inflowing currents prevail $(60 \%$ of cases vs. 53\% in the Suur Strait), they are also faster, and the current changes its direction less frequently than in other straits of the Väinameri.

Between 20 and 23 October 1998 we observed tongues of more saline (6.5 PSU vs. 5.5-5.7 PSU) and colder $\left(7.1^{\circ} \mathrm{C}\right.$ vs. $\left.7.4-8.5^{\circ} \mathrm{C}\right)$ water penetrating through the grid of islets between the WB and the EB. Despite the prevalence of fresh western winds during the measurements and several days before, the

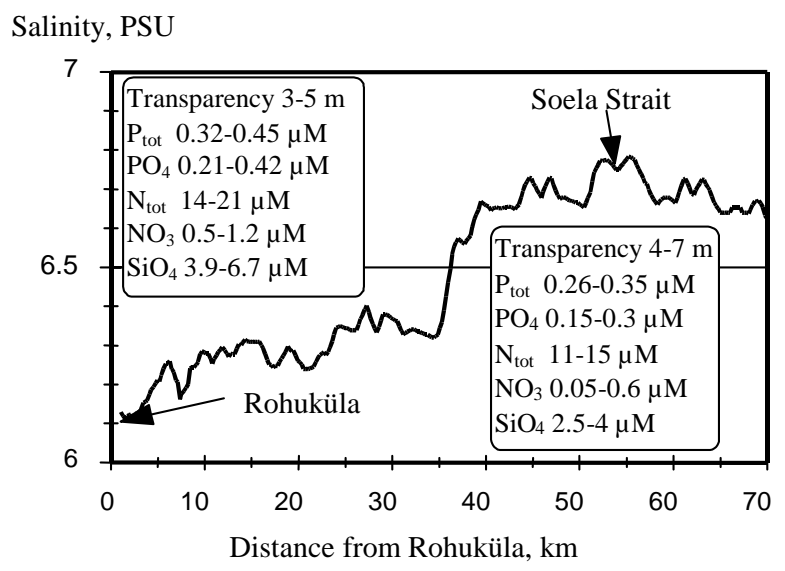

Fig. 7. Section of salinity through the sub-front from Rohuküla to the Soela Strait area on 17 October 1997. Hydrochemical situation in both sides of the sub-front is given in the text boxes. 
tongues were relatively small and did not occupy more than $10 \%$ of the area of the EB. Small E-W flow capability through the WB and, on the contrary, highly dynamic nature of the EB are also confirmed by the horizontal flux charts (Figs. 3b, $4 \mathrm{~b}, 5 \mathrm{a})$.

According to our model analysis, winds between $200^{\circ}$ and $20^{\circ}$ tend to produce inflows of the Baltic Proper waters through the Soela Strait. There might be infrequent deviations from that regularity due to sea level differences acting occasionally in the opposite direction and short-term inertness of processes. In addition, winds between $20^{\circ}$ and $90^{\circ}$ bring similar marine waters to Kassari Bay through the Hari Strait if the front has not moved too far in the north due to previous outflow event. Only continuous winds between $90^{\circ}$ and $200^{\circ}$ carry less saline and nutrient rich waters of the Gulf of Riga origin to the WB. Such an event must last about 10 days in the case of strong winds. Probably it is rare, except in cold winters with ice cover in the Väinameri, when eastern winds may indeed last that long.

\section{Local nutrient and pollution load versus currents and resuspension}

The possible influence of Matsalu and Haapsalu bays on the nutrient regime of the Väinameri deserves additional discussion. The largest source of nutrients, the Kasari River, has an estimated annual nutrient load of about $2000-2400 \mathrm{t} \mathrm{N}$ tot, 70-100 t $\mathrm{P}_{\text {tot }}, \quad 40 \mathrm{t} \mathrm{PO}_{4}, 1000 \mathrm{t} \mathrm{NO}_{3}$, and $1900 \mathrm{t} \mathrm{BOD}_{7}$ (Porgassaar, 1993; Protection..., 1995). Our investigations show, that the meridional water exchange processes can drive as much as $50 \mathrm{~km}^{3}$ of water in one direction during some months. Typical seasonal (half-year) cumulative flows are $30-80 \mathrm{~km}^{3}$ for the Suur and Hari straits (Suursaar \& Astok, 1998). Nutrient amounts carried by such flows during half a year are about 10-20 times as large as the local pollution load entering from the Kasari River during half a year.

Actually this factor could be even higher, as the pollution load has decreased during the last 10 years. Transformation processes inside Matsalu Bay should be also considered. The typical nutrient concentrations in Matsalu Bay before the spring bloom (in April) are $50 \mu \mathrm{M}$ for $\mathrm{N}_{\text {tot }}$ and around $1.3 \mu \mathrm{M}$ for $\mathrm{P}_{\text {tot }}$ (Porgassaar $\&$ Simm, 1985). Considering that the water volume of the bay is $0.1 \mathrm{~km}^{3}$ (10\% of the Kasari annual runoff), the nutrient pool of the bay is about $70 \mathrm{t}$ of nitrogen (3\% of the annual load) and $4 \mathrm{t}$ of phosphorus (5\% of the annual load). This shows that biogeochemical transformation processes reduce the impact of the riverine load and roughly only one third of the nitrogen load and half of the phosphorus load are exported from Matsalu Bay to the Väinameri. According to Porgassaar (1993) in Matsalu Bay a high inverse correlation $(r=-0.87)$ exists between $\mathrm{N}_{\text {tot }}$ and salinity, which shows good counteraction to the excessive nitrogen loads. Quite often there is no marked difference between nutrient concentrations in the Väinameri and in the western section of Matsalu and Haapsalu bays as the dilution rate is high. Efficient losses due to photosynthesis and sedimentation appear in the very vicinity of the input source. The role of 
reeds (Phragmites australis and Typha angustifolia, covering an area of about $30 \mathrm{~km}^{2}$ ) is also substantial. Thus, local pollution from these bays has a relatively limited effect on the state of the Väinameri.

For estimating the influence of resuspension we can calculate the $\mathrm{P}_{\text {tot }}$ pool of the Väinameri before (average $\mathrm{P}_{\text {tot }}$ content $\left.30 \mu \mathrm{g} / \mathrm{L}\right)$ and during a storm $\left(\mathrm{P}_{\text {tot }}\right.$ values $60-100 \mu \mathrm{g} / \mathrm{L}$ ). This calculation yields a short-term excess of 300-700 t of suspended $\mathrm{P}_{\text {tot }}$, which is about 3-8 times more than the estimates of annual $\mathrm{P}_{\text {tot }}$ load from the Kasari River (70-100 t) and Haapsalu (about $10 \mathrm{t}$ ). It is not fully clear how active that resuspended material exactly is in relation to primary production. Obviously the landbased "fresh" nutrient input is an important factor, but the above-described simple calculations show that phosphorus will be involved in continuous vertical turnover before the particles are exported to the deep basins of the Baltic Sea or buried into inactive layers of bottom sediments.

\section{CONCLUSIONS}

1. The Väinameri is a highly dynamic water body where the main factors that determine the situation are water exchange processes forced by the two major nearby basins and resuspension events during storms. The hydrophysical and hydrochemical front, dividing the waters of the Baltic Proper and the more polluted Gulf of Riga, fluctuates northwards or southwards, and the local conditions are frequently overrun by such excursions. The seasonal component of the frontal motions is governed by the seasonal and interannual changes in the large-scale atmospheric circulation scheme above the North Atlantic.

2. Resuspension events due to currents and surface waves shape the local conditions in relation to phosphorus concentrations while the frontal movements do the same in the case of nitrogen. High turbidity, about a 2-3-fold increase in phosphorus concentrations, and considerable displacement of bottom sediments occur during storms.

3. As the variability of the hydrophysical and -chemical parameters is remarkably high, the Väinameri is not suitable for low-frequency water quality monitoring and only intensive process-oriented studies are justified there.

4. On the basis of hydrodynamic behaviour two sub-basins can be defined in the Väinameri. The eastern part has about $85 \%$ of the water exchange, lower salinity, and higher nutrient concentrations. This sub-basin is strongly linked with the Gulf of Riga. In the western section (Kassari Bay) hydrological conditions are more marine and less variable. Accumulation conditions prevail in the extensive central part of that sub-basin, due to smaller velocities.

\section{ACKNOWLEDGEMENT}

The study is supported by the Estonian Science Foundation (grant No. 4057). 


\section{REFERENCES}

Astok, V., Otsmann, M. \& Suursaar, Ü. 1999. Water exchange as the main physical process in semi-enclosed marine systems: The Gulf of Riga case. Hydrobiologia, 393, 11-18.

Berzinsh, V. 1995. Hydrology. In Ecosystem of the Gulf of Riga Between 1920 and 1990. Academia 5 (Ojaveer, E., ed.), pp. 7-31. Estonian Acad. Publ., Tallinn.

Bowman, M. \& Esaias, W. (eds.) 1977. Oceanic Fronts in Coastal Processes. Springer-Verlag, Berlin.

Davis, R. A. \& Hayes, M. D. 1984. What is a wave-dominated coast? Mar. Geol., 60, 313-329.

Gidhagen, L. 1984. Coastal upwelling in the Baltic - presentation of satellite and in situ measurements of the sea surface temperatures indicating coastal upwelling. SMHI Rep. Hydrol. Oceanogr., 37.

Haupt, B. J., Stattegger, K. \& Seidov, D. 1999. SEDLOB and PATLOB: Two numerical tools for modeling climatically-forced sediment and water volume transport in large ocean basins. In Computerized Modeling of Sedimentary Systems (Harff, E. J., Lemke, W. \& Stattegger, K., eds.), pp. 115-147. Springer, New York.

Hayter, E. J., Bergs, M. A., Gu, R., McCutcheon, S. M., Smith, S. J. \& Whiteley, H. J. 1998. HSCTM-2D, a Finite Element Model for Depth-Averaged Hydrodynamics, Sediment and Contaminant Transport. Manual. National Exposure Research Laboratory, Athens, U.S.

HELCOM. 1993. Second Baltic Sea pollution load compilation. Baltic Sea Environ. Proc., 45.

HELCOM. 1996. Third periodic assessment of the state of the marine environment of the Baltic Sea, 1989-93; Background document. Baltic Sea Environ. Proc., 64B.

Huttula, T. 1994. Modelling the transport of suspended sediment in shallow lakes. Academic dissertation. University of Helsinki.

Jiang, W., Pohlmann, T., Sündermann, J. \& Feng, S. 2000. A modelling study of SPM transport in the Bohai Sea. J. Mar. Syst., 24, 175-200.

Kirikal, R. F. 1967. Wave regime in the Muhu Straits and prognosis of its elements. In Collection of Papers of Tallinn Hydrometeorological Observatory, Vol. 5, pp. 12-21. Tallinn (in Russian).

Kull, A. \& Meitern, H. 1998. Changes in wind climate. In Country Case Study on Climate Change Impacts and Adaptation Assessments in the Republic of Estonia (Tarand, A. \& Kallaste, T., eds.), pp. 23-25. Report to UNEP/GEF. Stockholm Environment Institute Tallinn Centre, Estonian Ministry of Environment, Tallinn.

Kullas, T., Otsmann, M. \& Suursaar, Ü. 2000. Comparative calculations of flows in the straits of the Gulf of Riga and the Väinameri. Proc. Estonian Acad. Sci. Eng., 6, 284-294.

Laima, M. J. C., Lund-Hansen, L. C., Christiansen, C. \& Kunzendorf, H. 1994. Nutrient fluxes in a coastal basin: The effect of resuspension on the dynamics of dissolved P pools. In Proc. of the 19th CBO, Sopot, Poland. Vol. II, pp. 518-527.

Li, Y., Huang, W. \& Fang, M. 1998. An algorithm for the retrieval of suspended sediment in coastal waters of China from AVHRR data. Continental Shelf Res., 18, 487-500.

Lou, J. \& Schwab, J. 2000. A model of sediment resuspension and transport dynamics in southern Lake Michigan. J. Geophys. Res., 105 (C3), 6591-6610.

Lutt, J. 1985. Bottom Sediments of the Väinameri. Valgus, Tallinn (in Russian).

Mardiste, H. 1974a. Kassari lahe hüdroloogilisest režiimist. In Eesti Geograafia Seltsi aastaraamat 1973 (Merikalju, L., ed.), pp. 91-102. Valgus, Tallinn.

Mardiste, H. 1974b. Hydrographical and hydrological features of the Muhu Straits (Väinameri). Ph.D. Thesis, Abstract. Tartu (in Russian).

Mardiste, H. \& Kaasik, T. 1985. Matsalu lahe ja Kasari jõe hüdroloogiline režiim. In Matsalu rahvusvahelise tähtsusega märgala (Kumari, E., ed.), pp. 15-25. Valgus, Tallinn.

Massel, S. 1999. Fluid Mechanics for Marine Ecologists. Springer-Verlag, Berlin.

Otsmann, M., Astok, V. \& Suursaar, Ü. 1997. A model for water exchange between the Baltic Sea and the Gulf of Riga. Nord. Hydrol., 28, 351-364. 
Otsmann, M., Suursaar, Ü. \& Kullas, T. 2001. The oscillatory nature of the flows in the system of straits and small semienclosed basins of the Baltic Sea. Continental Shelf Res., 21, 15771603.

Peterson, U., Aunap, R. \& Eilart, J. 1998. Eestimaa nähtuna kosmosest. Koolibri, Tallinn.

Pitkänen, H. 1994. Eutrophication of the Finnish coastal waters: Origin, fate and effects of riverine nutrient fluxes. Publ. Water Environ. Res. Inst., 18. Helsinki.

Porgassaar, V. 1993. Content and distribution of phosphorus and nitrogen in the coastal waters of West Estonia. Proc. Estonian Acad. Sci. Ecol., 3, 166-180.

Porgassaar, V. \& Simm, H. 1985. Matsalu lahe hüdrokeemiline režiim. In Matsalu - rahvusvahelise tähtsusega märgala (Kumari, E., ed.), pp. 26-35. Valgus, Tallinn.

Protection of the Coastal Wetland Area - Matsalu Catchment Area. 1995. Estonian-Swedish Joint Project. Tallinn, Stockholm.

Puls, W., Pohlmann, T. \& Sündermann, J. 1999. Model simulation of temporal variability of suspended matter in the North Sea. In Computerized Modeling of Sedimentary Systems (Harff, E. J., Lemke, W. \& Statteger, K., eds.), pp. 37-62. Springer, Berlin.

Suursaar, Ü. 1994. Estonian marine monitoring 1968-1991: Results and evaluation. Finn. Mar. Res., 262, 123-134.

Suursaar, Ü. \& Astok, V. (eds.) 1996. Studies on Measuring and Modelling of the Water and Nutrient Exchange of the Gulf of Riga. EMI Rep. Ser., 3.

Suursaar, Ü. \& Astok, V. (eds.) 1998. More Studies on the Water Exchange and the Nutrients of the Gulf of Riga. EMI Rep. Ser., 9.

Suursaar, Ü., Astok, V., Kullas, T., Otsmann, M. \& Nõmm, A. 1996. Väinameri - the buffer zone in the water and nutrient exchange between the Gulf of Riga and the Baltic Proper. In Estonia. Geographical Studies (Punning, J.-M., ed.), pp. 5-28. Estonian Acad. Publ., Tallinn.

Suursaar, Ü., Otsmann, M. \& Kullas, T. 2000. Exchange processes in the Väike Strait (Baltic Sea): Present, past, future. Proc. Estonian Acad. Sci. Biol. Ecol., 49, 235-252.

Suursaar, Ü., Kullas, T. \& Otsmann, M. 2001. Hydrodynamical modelling of sea levels in the Väinameri and Pärnu Bay. Proc. Estonian Acad. Sci. Eng., 7, 222-234.

\section{HOOVUSTE JA LAINETE MÕJU VÄINAMERE ÖKOLOOGILISTELE TINGIMUSTELE}

\section{Ülo SUURSAAR, Tiit KULLAS ja Mikk OTSMANN}

Tuginedes 1993.-1999. aasta välitöödel saadud andmestiku analüüsile ning hüdrodünaamilisele modelleerimisele on uuritud hoovuste ja lainetuse mõju Väinameres valitsevatele tingimustele. On esitatud hoovuste ruumilise horisontaalse jaotuse kaardid ning sissejuhatav uurimus Väinamere resuspensiooniprotsesside kohta. Tegu on väga dünaamilise veekoguga, kus Liivi lahe ja Läänemere avaosa vahelistest veevahetusprotsessidest tingitud hüdrokeemilise frondi liikumised ning tormide poolt merepõhjast hõljuvasse olekusse tõstetud aine kujundavad oluliselt mereala seisundit. Tormide ajal toimub setete ümberpaiknemine, kahaneb vee läbipaistvus ning 2-3 kordselt kasvab vee üldfosfori sisaldus. Resuspensiooni põhjusena domineerib väinades hoovus ning madalamas rannikuvööndis lainetus. Väinamere idaosa on magedam ning hüdrodünaamilises mõttes aktiivsem, lääneosa on merelisem, passiivsem ning suuresti akumulatiivne. 